\title{
АПЕК-ИЙН ҮЙЛ АЖИЛЛАГААНЫ ЯВЦ БА ӨНӨӨГИЙН БАЙДАЛ
}

Д.Батжаргал

ОУСХ-ийн эрдэм шинжсилгээний ажсилтан, магистр

АПЕК буюу Ази-Номхон далайн бvс нутгийн эдийн засгийн хамтын ажиллагааны байгууллага нь 1989 оны 11 дvгээр сард Австралийн нийслэл Канберрад энэ бvс нутгийн 12 орны гадаад хэргийн болон гадаад худалдаа, эдийн засгийн сайд нар “Ази-Номхон далайн эдийн засгийн хамтын ажиллагаa /Asia-Pacific Economic Cooperation буюу APEC/" гэсэн форумыг зохион байгуулснаар АПЕК-ийн эхлэл тавигдаж, энэхүҮ бага хурал буюу форум нь жил бүр тогтмол хуралдсаар байна. АПЕК-нь «байгууллага» гэхээсээ илүҮ тодорхой зорилт дээр нэгдсэн бүс нутгийн эдийн засгийн хамтын ажиллагааны «Vйл явц» болж, бүс нутгийн орнуудын өсөн нэмэгдэж байгаa хамтын ажиллагаa, эдийн засгийн тvргэн өсөлт, худалдаa, хөрөнгө оруулалтыг либералчлалын аргаар баталгаажуулах зорилготой. Дэлхийн хүн амын 40 хувийг эзэлдэг форумын гишүүн орнуудад олон улсын эдийн засгийн тал хувь нь ноогддог ба дэлхийн ДНБ-ний 54 хувь, олон улсын худалдааны эргэлтийн 44 хувийг бүрдүүлдэг байна.

АПЕК-ийн форумыг зохион байгуулсан улс орон болоод шийдвэрлэсэн асуудлын тухай:

№ $\quad$ Хэдэн онд $\quad$ Улсын нэр $\quad$ Нийслэл $\quad$ Форумаар шийдвэрлэсэн асуудал

$1 \quad$ 1989.11.06 Австрали Канберра “АПЕК-ийн чиглэл”-ийг тодорхойлов

2 1990.07.29 Сингапур Сингапур “Байгууллагын үйл ажиллагааны зорилт бол хуралдааны нээлттэй системийг хөгжүүлэх” гэсэн сэдвээр хэлэлцэв.

3 1991.11.12 Өмнөд Солонгос Сөүл Үйл ажиллагааны ажлын хэсгүүдийг байгуулж, төсвийг батлав.

4 1992.09.10 Тайланд Бангкок АПЕК-ийн нарийн бичгийн дарга нарийн газрыг Сингапурт төвлөрүүлэхээр шийдэв.

5 1993.11.19 АНУ Сиетл Сайд нарын зэрэгцээ улс орнуудын төрийн тэргүүн нарыг оролцуулахаар болжээ.

6 1994.11.10 Индониз Богор Худалдаа, хөрөнгө оруулалтыг либералчилах хүрээг тодорхойлсон “Богор зорилго” -ын тунхаг батлав.

7 1995.11.19 Япон Осака “Богорын Тунхаглалын заалтуудыг нарийсган тодорхойлов.

8 1996.11.25 Филиппин МанилАПЕК-т зориулсан үйл ажиллагааны “Манилын төлөвлөгөө"-г гаргав.

9 1997.11.24 Канад Ванкувер “Нэг гэр бүл” гэсэн тунхаг батлав.

10 1998.11.17 Малайз Куала лумпур“21-р зуун руу алхах АПЕК-ийн үйл явц” гэсэн тунхаг батлав. 
11 1999.09.12 Шинэ Зеланд Окланд “АПЕК-ийн хүчирхэг өрсөлдөөн болон эмэгтэйчүүдийн АПЕК-т оролцох хүрээ”-ний талаар хэлэлцэв.

12 2000.11.15 Бруней Бандар сэри Веган “Мэдээллй̆н технологийн саммит” -ын төлөвлөгөөг гаргав.

$\begin{array}{llll}13 & 2001.10 .20 & \text { БНХАУ } & \text { Шанхай } \\ 14 & 2002.10 .26 & \text { Мексик } & \text { Лос-Каво } \\ 15 & 2003.10 .20 & \text { Тайланд } & \text { Бангкок }\end{array}$

16 2004.11.20 Чили Сант-Яго “Нэг их гэр бүл, бидний ирээдүй”сэдэвт хурлаар “СантЯгогийн тунхаглал” гаргасан

17 2005.11.18 Өмнөд Солонгос Пусан

$18 \quad$ 2006.11.18 Вьетнам Ханой

19 2007.09.08 Австрали Сидней

20 2008.11.22 Перу Лима Эдийн засгийн хямралаас гарах арга “Лимагийн тунхаг” батлав

21 2009.11.14 Сингапур Сингапур Сингапурын тунхаг

22 2010.11.13 Япон Яокохама Яокохамагийн тунхаг

232011.11 .12 АНУ Хонололу Эрчим хүч болон эрчим хүчний аюулгүй байдал, бүс нутгийн эдийн засгийн өсөлтийг хангах, ажлын байр нэмэгдүүлэхээр хэлэлцэв.

242012 ОХУ Владивосток

252013 Индонез Манадо/ Бали

АПЕК-ийн либералчлалын vйл явц заавал биелvулэх шинжтэй амлалт, дvрмэнд захирагдах бус харилцан зөвшөөрсөн зарчмууд дээр тулгуурласан сайн дурын амлалтанд захирагддагаараа ДХБ-аас ялгагдах гол ялгаатай юм. АПЕК-ийн бага хурал нь АПР (АНдБн)дахь чөлөөт худалдаа, хөрөнгө оруулалт, эдийн засгийн хамтын ажиллагаанд тус дэм үзүүлэх байгууллага болон хувирч бас бага хурлын статус нь сайд нарын түвшингээс дээшилж дээд түвшний болсон. Өнөөдөр АПЕК-ийн орнууд эдийн засгаа амжилттай хөгжүүлж, энэ бүс нутаг нь эдийн засгийн өсөлтөөр бусад бүс нутгийг давамгайлж, улмаар дэлхийн эдийн засгийн хөгжлийн нэг төв болж байна. Байгуулагдсан эхний 10 жилдээ АПЕК нь 10 сая ажлын байр бий болгосон.

АПЕК-ийн нэг том зорилт нь эдийн засгийн чөлөөт хөрөнгө оруулалтын стратегийн бодлогыг 20102020 он хvртэл ve шаттай хэрэгжvvлж, тус бүс нутгийн хөгжингүй орнуудыг 2010 он гэхэд, хөгжиж буй орнуудыг 2020 он гэхэд чөлөөт болон нээлттэй худалдаа, хөрөнгө оруулалтын тогтолцоонд шилжүүлэхээр Манилын төлөвлөгөөгөөр зорилт болгон тавьсан. ЭнэхүҮ зорилтоороо бүс нутгийн эдийн засгийн хөгжилд дорвитой хувь нэмэр оруулах, худалдаа, үйлчилгээ, хөрөнгө оруулалтын 
чөлөөтэй урсгал, нөхцөл бий болгохоор ажиллаж байна. Тухайлбал, зах зээлийг аль болох нээлттэй болгох зорилгоор татвар болон татварын бус хориг саад vл хэрэглэх, зах зээлд нэвтрэхэд тус дөхөм үзүүлэх үйлчилгээг сайжруулах, хөрөнгө оруулалтын чөлөөт горимын тогтолцоог бүрдүүлэх, зах зээлийн аливаа vйл ажиллагааны vнэ, өртгийг хямдруулах, чөлөөт болон үр ашигтай дэд бүтцийн салбарыг бий болгох, эдийн засаг, техникийн хамтын ажиллагааг бэхжүүлэхээр зорин ажиллаж байна.

2011 оны 11-р сарын 13-нд АПЕК-ийн дээд хэмжээний албан ёсны бус 19 дүгээр форум АНУ-гийн Хавайн Хонолулуд зохиогдлоо. Форумаар хэлэлцсэн гол асуудлууд нь эрчим хүчийг үр ашигтай зарцуулж, эрчим хүчний аюулгүй байдлыг сайжруулах замаар бүс нутгийн эдийн засгийн өсөлтийг хангах, ажлын байр нэмэгдүүлэхэд чиглэж байв. Түүнчлэн хуралдаанаас хөрөнгө оруулалт, бараа үйлчилгээний арилжаан дахь хоригийг түдгэлзүүлсэн байгааг 2013 он хүртэл сунгасан байна. Форумаар Ази-Номхон далайн орнуудын удирдагчид бүс нутаг дахь чөлөөт худалдааг өргөжүүлж, хөрөнгө оруулалтыг нэмэгдүүлэхэд саад болж буй зүйл болон тарифийн асуудал, байгалийн гаралтай бүтээгдэхүүний тарифийг бууруулахыг дэмжсэн бол Хятад болон хөгжиж буй бусад орны удирдагчид өөрсдийн зах зээл дэх нөлөөллийг авч үзэхийг анхааруулсан байна. АПЕК-ийн орнууд Ази-Номхон далайн чөлөөт худалдааны бүс байгуулахаар 2010 онд Транс-Номхон далайн эдийн засгийн түншлэлийг бий болгосон бөгөөд бүс нутгийн хүрээнд хэрэгжүүлэх асуудлыг 2012 оны эхээр эцэслэн шийдвэрлэхээр тохиролцжээ. Энэхүү шинэ нэгдэл байгуулах тухай БНХАУ-ын зүгээс нэлээд шүүмжлэлтэй хандаж байгаа бол Азиас Европ руу ОХУ-аас дамжин өнгөрөх транзит тээвэрлэлтийн хэмжээг нэмэгдүүлснээр ОХУ-ын эдийн засагт жилд 50 тэрбум ам.долларын ашиг орно хэмээн ОХУ үзэж байна. Мөн АПЕК-ийн орнуудыг эрчим хүчний нөөцийн хэрэглээгээр хангахад бэлэн буйгаа ч Орос мэдэгдсэн юм.

АПЕК-ын удирдагчдын нэг БНХАУ-ын ерөнхийлөгч Ху Жиньтао: АПЕК-ын гишүүд худалдааны хөрөнгө оруулалтыг чөлөөтэй, дөхөм болгох, Ази-Номхон далайн бүс нутгийн ногоон өсөлтийн хамтын ажиллагааг гүнзгийрүүлэх, эдийн засгийн бүтцийн өөрчлөлт, цэгцтэй хамтын ажиллагааг эрчимжүүлэх ажлыг бүх талаар урагшлуулахыг уриаллаа. Талууд бүс нутгийн дэд бүтцийн харилцаа, мэдээлэлжүүлэлтийн бүтээн байгуулалтыг эрчимжүүлж, бараа эргэлт, үйлчилгээний явц дахь хүндрэлийг арилгаж, бараа эргэлтийн өөрийн өртгийг бууруулж мөн жижиг дунд аж ахуйн нэгжүүдийн хөрөнгө нийлүүлэхэд хүндрэлтэй байгаа асуудлыг зохицуулах талаар нааштай арга хэмжээ авч, тэднийг дэлхийн аж үйлдвэрийн сүлжээнд орохыг урамшуулбал зохино. Түүнчлэн засгийн газрын чадавхийг нэмэгдүүлж, бүтээлчээр ажиллахыг дэмжих ёстой. АПЕК нь “Богорын зорилго”-ын дагуу тухайн бүс нутгийн худалдааны хөрөнгө оруулалтыг чөлөөтэй, дөхөм болгох, бүс нутгийн эдийн засгийн интегралчлалыг гүнзгийрүүлэх, эдийн засгийн салбарын техник мэргэжлийн хамтын ажиллагааг эрчимжүүлж, холбогдох талуудын хамтын хөгжлийг ахиулахыг бүх талаар урагшлуулбал зохино. Мөн ногоон өсөлтийн хамтын ажиллагааг гүнзгийрүүлэх явцад гишүүд байгаль орчны бүтээгдэхүүн ба үйлчилгээний холбогдох техникийг дэлгэрүүлж, хамтын ажиллагаагаа эрчимжүүлж, хөгжилд туслах явцдаа гишүүдийн байгаль орчны салбарын үйлдвэрлэлийг хөгжүүлж, худалдаа, байгаль орчин, хөгжил хамтын ялалтыг биелүүлэх ажиллагаанд илүҮ их хүчин чармайлт гаргаж, шинэ хүндрэл гарахаас сэргийлэх ёстой гэжээ. 
Европын холбоонд хүнд хэцүү цаг үе тохиож, олон улсын зах зээлийг уналтаас авч гарах үүрэг хариуцлага өнөөдөр АПЕК-д ногдож буй билээ. Гишүүн орнууд эдийн засгийн эгзэгтэй цаг мөчид чуулж, дэлхийн ирээдүйг шийдэх түүхэн чухал үүрэг хариуцлага оногдсон юм.

АПЕК-ийн нөлөө бүхий гиᄀшүүд ОХУ болон Япон улсын эдийн засгийн түншлэлийн шинэ хуудас нээж, эдийн засгийн шинэт $\urcorner$ гл, худалдааны салбарт нягт хамтран ажиллах гэрээ байгуулснаар хоёр тал урд өмнөхөөсөө илүү дот $\neg$ хорилцаа тогтооно гэдэгт итгэлтэй байна. Хэдийгээр талууд эдийн засаг хулдалᄀдааны салбарт эв найрамᄀдалтай харилцах алхам хийсэн ч газар нутгийн маргаантай асуудал байсаар байна. Үүнээс үүдэн арай гэж бүлээсч буй харилцаа хөрч болзошгүй тул олон улсын зүгээс газар нутгийн маргааныг юуны түрүүнд таслан зогсоохыг уриалсан байна.

Энэ удаагийн форумаар хэлэлцсэн хурцадмал асуудᄀлын нэг нь Ираны цөмийн үйлдвэрүүд юм.

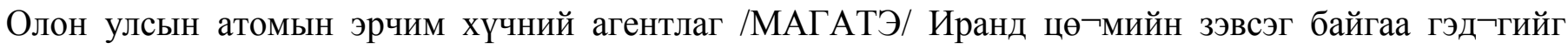
баталсан. АНУ юуны түрүүнд Ираны эсрэг хориг арга хэмжээг хамгийн дээд хэмжээгээр чангалж,

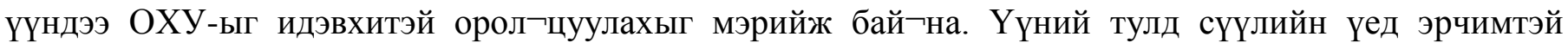
сайжирч буй харилцаа хамтын ажиллагааг ашиглахын зэрэгцээ Дэлхийн худалдааны байгууллагын гишүүнчлэлээр дулдуйдаж байна.

БНХАУ-ын гадаад худалдааны болон санхүүгийн бодлого нь юанийн ханшийг хүчээр барьж шударга бус ашиг олж байгааг хатуу шүүмжиллээ. Дэлхийн эдийн засгийн тодорхой нөхцөлд ажлын байр бий болгох худалдаа эргэлтийг сайжруулах тал дээр улсууд хамтран ажилласнаар эдийн засгийн хямралаас гарч болох юм гэж форумд оролцогсод дүгнэсэн.

АНУ-ын ерөнхийлөгч Барак Обама: "Бид энэ удаагийн форумаар дэлхий дахинд тулгараад буй эдийн засгийн хямралыг зогсоох арга хэмжээг хэлэлцэж чадна гэдэгтэй итгэлтэй байна. Бид хамтдаа чөлөөт худалдааны бүсийг хэд хэдэн газар байгуулж, улмаар ажлын байр, шинэ байрыг нэмэгдүүлэн ирээдүйн зах зээлд түлхэц болохуйц хэрэгтэй зүйлийг хийж чадна" гэжээ. Уг форумд уригдан оролцсон Олон Улсын Валютын сангийн тэргүүн хатагтай Кристин Лагард “Евро бүсийн хямралыг шийдэхгүй бол дэлхийн эдийн засгийн хямрал унасаар байх болно. Эдийн засаг улам бага өсөж улам олон хүн ажлаас халагдах болно” гэжээ.

АПЕК-ийн форумын үеэр Япон улсын ерөнхий сайд Наото Кантай БНХАУ-ын ерөнхийлөгч Ху Жиньтао албан ёсны уулзалт хийснээр газар нутгийн маргааны талаар ахиц гарсан. Мөн ОХУ болон Япон улсын хооронд иймэрхүҮ маргаан байсан нь нааштайгаар шийдэгдсэн.

Одоогоор АПЕК-т гишvvнээр элсэхээр 8 орон саналаа өгсөн бөгөөд тэдний дунд Монгол улс (2005.04.02 саналаа өгсөн) багтаж байгаа юм. Гэвч АПЕК-ийн байгууллага шинээр гишүүн элсүүлэхийг түр хойшлуулсаар байгаа.

Ашигласан материал

1. 2011.11.14 -ийн“人民日报” “Ардын өдрийн сонин” 1,2-p нүүр 人民日报社出版 北京.2011 年 
2. 2011.11.15-ны“人民日报” “Ардын өдрийн сонин” 1,2-p нүүр 人民日报社出版＼cjkstart北京.2011 年

3. Б.Балдоо “Ази-Номхон далайн бүс нутаг, эдийн засгийн хамтын ажиллагааны үйл явц” “Олон улс судлал” сэтгүҮл УБ.2001.№2 60-р тал

4. “亚太经合组织(АРЕС)”, “新亚洲”, “Шинэ Ази тив” 中央编译出版社 北京.1998 年 109-p тал

5. www.people.com.cn

6. www.google.mn 